\title{
FIRE DESIGN OF STEEL STRUCTURES
}

\author{
Anatolii V. Perelmuter \\ SCAD Soft, Kyiv, UKRAINE
}

\begin{abstract}
This paper describes new software features for the fire design of steel structures. This analysis is performed according to Eurocode. An example is used to demonstrate the role of secondary effects and show that the estimation based on the critical temperature may differ significantly from the revised calculation.
\end{abstract}

Keywords: fire design, thermal properties, critical temperature, secondary effects

\section{РАСЧЕТ ОГНЕСТОЙКОСТИ СТАЛЬНЫХ КОНСТРУКЦИЙ А.В. Перельмутер \\ НПО «СКАД Софт», г. Киев, УКРАИНА}

\begin{abstract}
Аннотация: Приводятся сведения об особенностях программной реализации модулей расчета стальных конструкций на огнестойкость. Методика расчета следует указаниям Еврокода. На примере демонстрируется роль вторичных эффектов и показывается, что оценка по критической температуре может существенно отличаться от уточненного расчета.
\end{abstract}

Ключевые слова: огнестойкость, теплотехнические свойства, критическая температура, вторичные эффекты

\section{BASIS OF FIRE DESIGN}

A structure is fire resistant when the necessary safety margin can be provided for a certain period of time. It is also necessary to take into account the variation of the thermal and mechanical properties of steel under the fire heating of the structure along with the mechanical actions.

Evaluation of fire resistance includes:

- determination of structural heating - a thermal analysis performed in order to predict the temperature (select the fire type) and structural heating patterns;

- strength analysis, which takes into account the variation of physical properties of the material under the action of high temperature.

The calculation is performed for one of the four standard variants of the temperature variation during a fire (Figure 1).

Thermal analysis of steel structures is greatly simplified due to the fact that high thermal conductivity of steel and relatively small thickness of bearing structures allow us to accept the hypothesis of a uniform temperature in the cross- section, which makes it possible to use analytical relationships between temperature, thermal conductivity $\lambda(T)$, specific heat $c(T)$ of steel and external temperature $T$ (Figure 2).

Moreover, it is assumed that the temperature of the element is constant along its length.

The strength analysis takes into account the variation of the mechanical properties of the material (Figure 3).

Since the structure was designed to take all active loads, and only dead and long-term loads are taken into account in the fire analysis, there is a certain safety margin characterized by the degree of utilization $\mu$.

The critical temperature can be determined for any degree of utilization $\mu$ as:

$$
\theta_{\text {crit }}=39,19 \ln \left(\frac{1}{0,9674 \mu^{3,833}}-1\right)+482 \text {. }
$$

Moreover, it is important to determine the time it takes to reach this temperature, so that it could be compared with the fire resistance time. 
Fire Design of Steel Structures

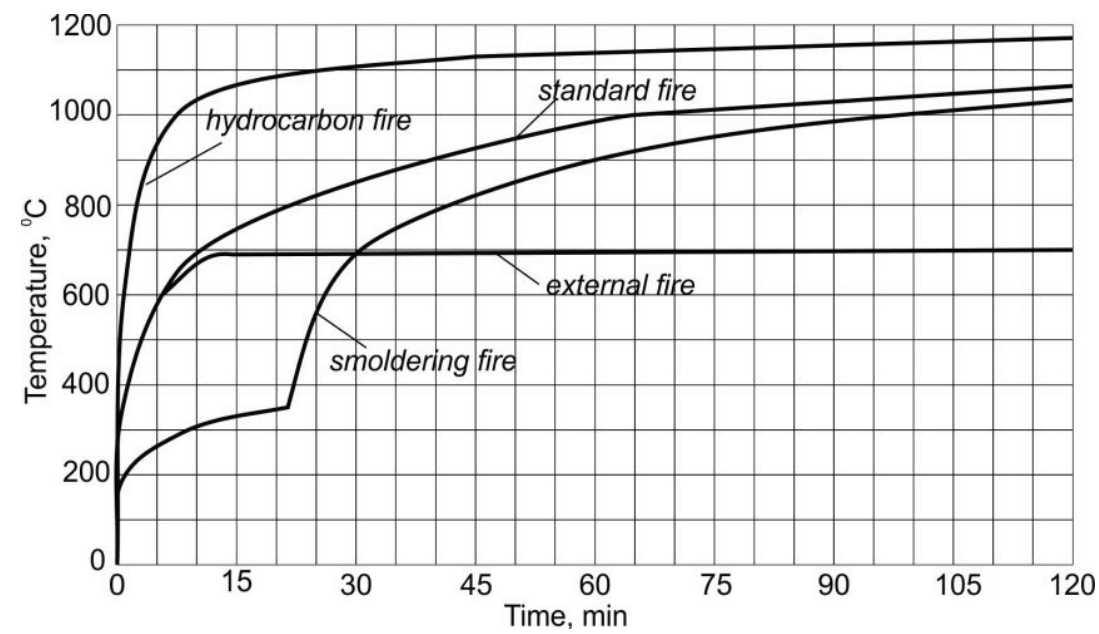

Figure 1. Temperature-time curve.
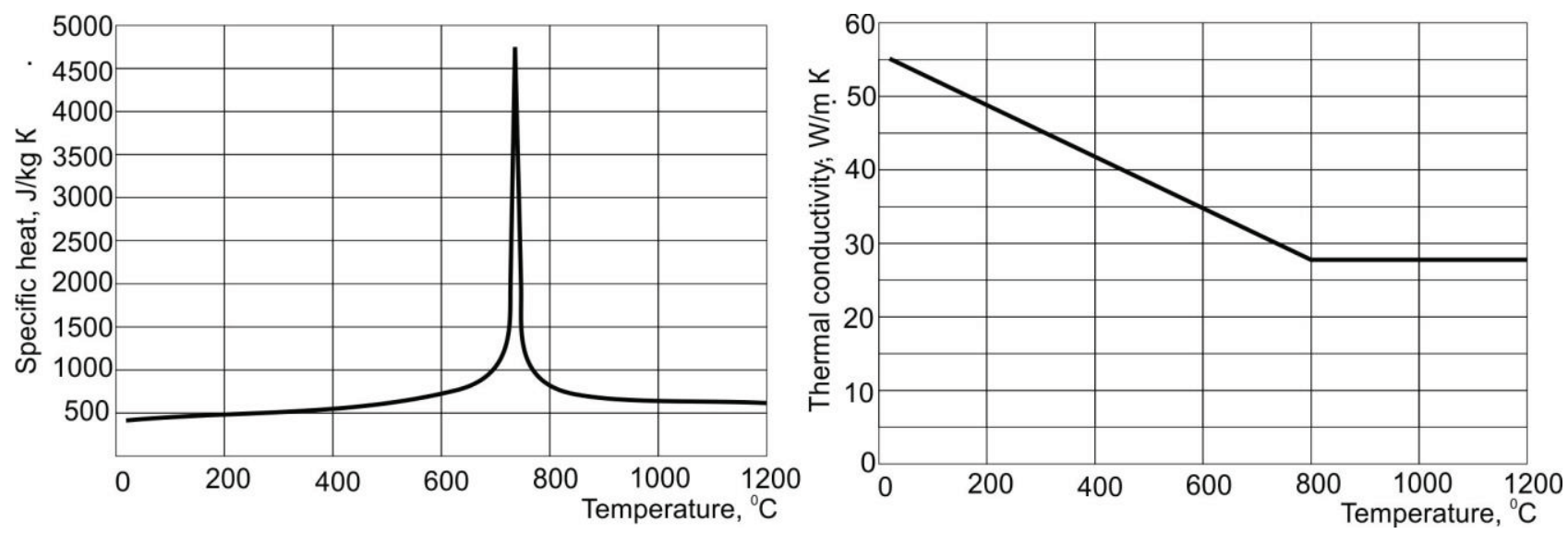

Figure 2. Variation of the thermal properties of steel.

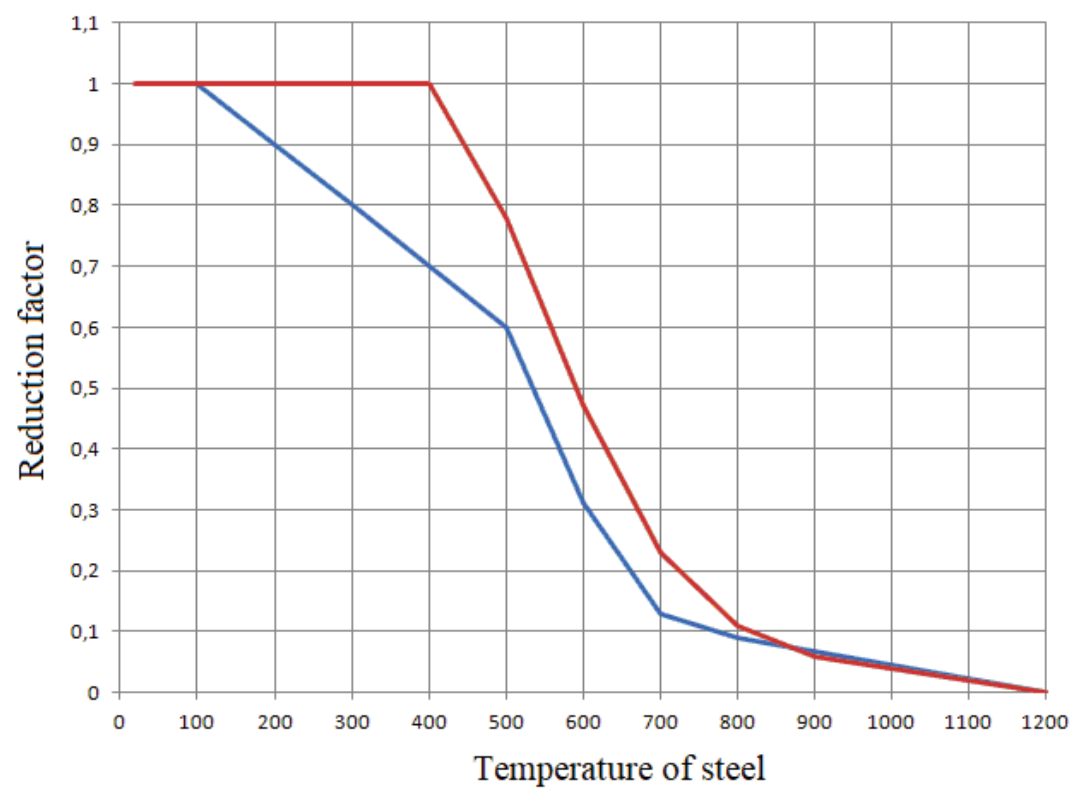

Yield point

Elastic modulus

Figure 3. Effect of heating on the mechanical properties of steel. 


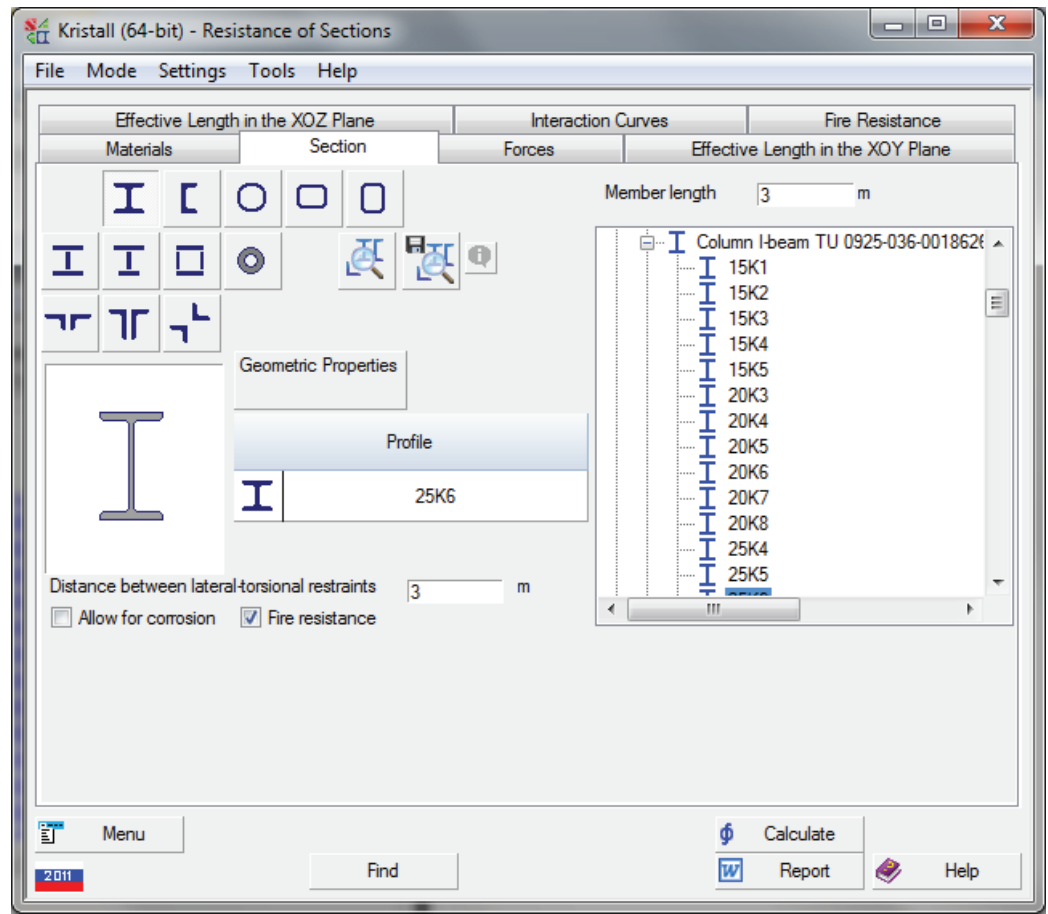

Figure 4. The Resistance of Sections dialog box with an active fire test mode.

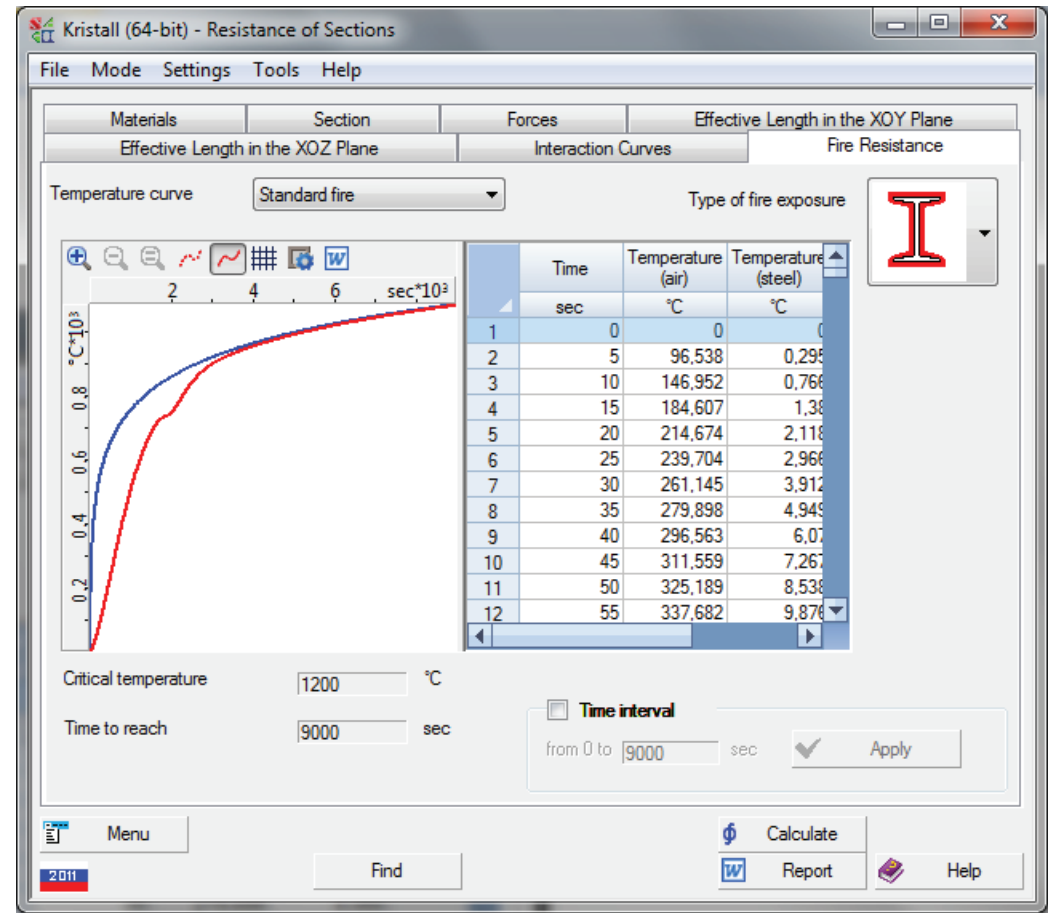

Figure 5. Results of the calculation.

\section{SOFTWARE INTERFACE}

Kristall enables to perform the fire design if the respective option is enabled in the Resistance of Sections mode (Figure 4).

The results of the calculation include (Figure 5):
- graph of the temperature increase for the selected fire;

- graph of the temperature variation of the structure;

- critical temperature;

- time to reach the critical temperature. 


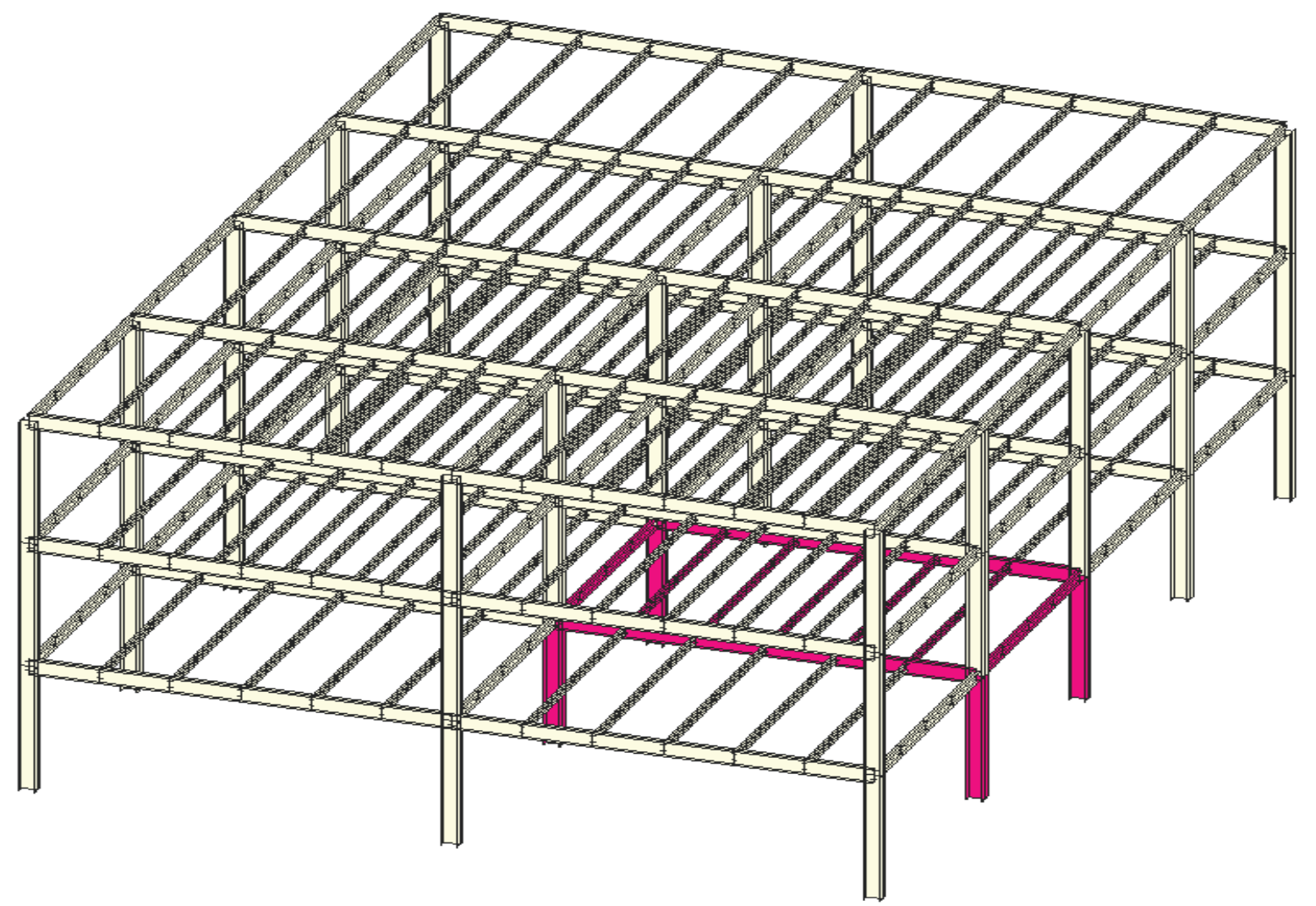

Figure 6. Frame.

\section{SECONDARY EFFECTS}

The role of secondary effects is demonstrated by an example. Let's consider a three-story building (Figure 6) with steel columns, beams, and minor beams. The floor is simply-supported on minor beams and only transfers the load to them without taking it. The fire action is applied in a section of the first floor shown in color in Fig. 6 The column cross-section is an I-beam $35 \mathrm{~K} 1$, GOST 26020-83, the beam cross-section is an Ibeam 46B1, GOST 26020-83, and a minor beam cross-section is an I-beam No. 20, GOST 823989.

The floor is assumed to be sufficiently fireresistant and therefore the columns are heated from 4 sides, and beams and minor beams from 3 sides.

The dead load on the floor is $\mathrm{G}=150 \mathrm{~kg} / \mathrm{m}^{2}$, the live load is $\mathrm{Q}=400 \mathrm{~kg} / \mathrm{m}^{2}$. The live load factor is taken as 0,25 .
A standard fire is considered when the temperature in the fire compartment varies according to the following equation

$$
\theta_{g}=20+345 \lg (8 t+1) \text {, }
$$

where $t$ is time in minutes. The heating of steel structural elements was calculated in increments, which was determined according to the following formula for the time interval $\Delta \mathrm{t}$

$$
\begin{aligned}
& \Delta \theta_{a}=\left(\frac{A_{m}}{V}\right) \frac{1}{c_{a} \rho_{a}}\left\{25\left(\theta_{g}-\theta_{a}\right)+\right. \\
& \left.+5,67 \cdot 10_{-8}\left[\left(\theta_{g}+273\right)^{4}-\left(\theta_{a}+273\right)^{4}\right]\right\} \Delta t^{\prime}
\end{aligned},
$$

where $\rho_{a}=78590 \mathrm{~kg} / \mathrm{m}^{3}$ is the density of steel. The results of the thermal analysis are given in the Table 1. This table also provides the values of the reduction factors for the elastic modulus 
and design resistance caused by the heating (Figure 7 and Figure 8).

\begin{tabular}{|c|c|c|c|c|c|c|c|c|c|}
\hline \multirow{2}{*}{$\begin{array}{c}\text { Time from the } \\
\text { start of the } \\
\text { fire, min }\end{array}$} & \multicolumn{3}{|c|}{ Temperature, ${ }^{\circ} \mathrm{C}$} & \multicolumn{3}{c|}{ Reduction factor $E$} & \multicolumn{3}{c|}{ Reduction factor $R_{y}$} \\
\cline { 2 - 12 } & Column & Beam & $\begin{array}{c}\text { Minor } \\
\text { beam }\end{array}$ & Column & Beam & $\begin{array}{c}\text { Minor } \\
\text { beam }\end{array}$ & Column & Beam & $\begin{array}{c}\text { Minor } \\
\text { beam }\end{array}$ \\
\hline 0 & 20 & 20 & 20 & 1,000 & 1,000 & 1,000 & 1,000 & 1,000 & 1,000 \\
\hline 1 & 41 & 44 & 64 & 1,000 & 1,000 & 1,000 & 1,000 & 1,000 & 1,000 \\
\hline 2 & 72 & 80 & 133 & 1,000 & 1,000 & 1,000 & 1,000 & 1,000 & 1,000 \\
\hline 3 & 99 & 112 & 200 & 1,000 & 1,000 & 1,000 & 1,000 & 1,000 & 1,000 \\
\hline 4 & 134 & 152 & 277 & 1,000 & 1,000 & 0,897 & 1,000 & 1,000 & 1,000 \\
\hline 8 & 291 & 326 & 625 & 0,878 & 0,832 & 0,297 & 1,000 & 1,000 & 0,510 \\
\hline 10 & 374 & 419 & 794 & 0,767 & 0,709 & 0,210 & 1,000 & 0,930 & 0,187 \\
\hline 12 & 461 & 514 & 947 & 0,653 & 0,560 & 0,131 & 0,830 & 0,770 & 0,116 \\
\hline 15 & 592 & 658 & 1128 & 0,333 & 0,280 & 0,037 & 0,522 & 0,344 & 0,033 \\
\hline
\end{tabular}

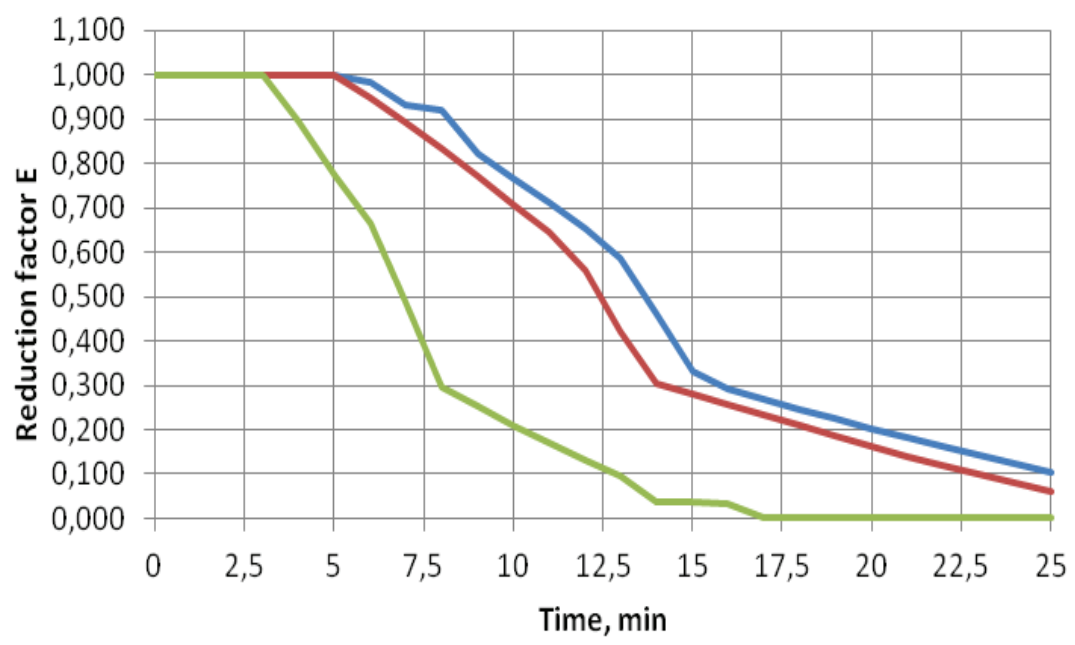

Column Beam Minorbeam

Figure 7. Reduction of the elastic modulus.

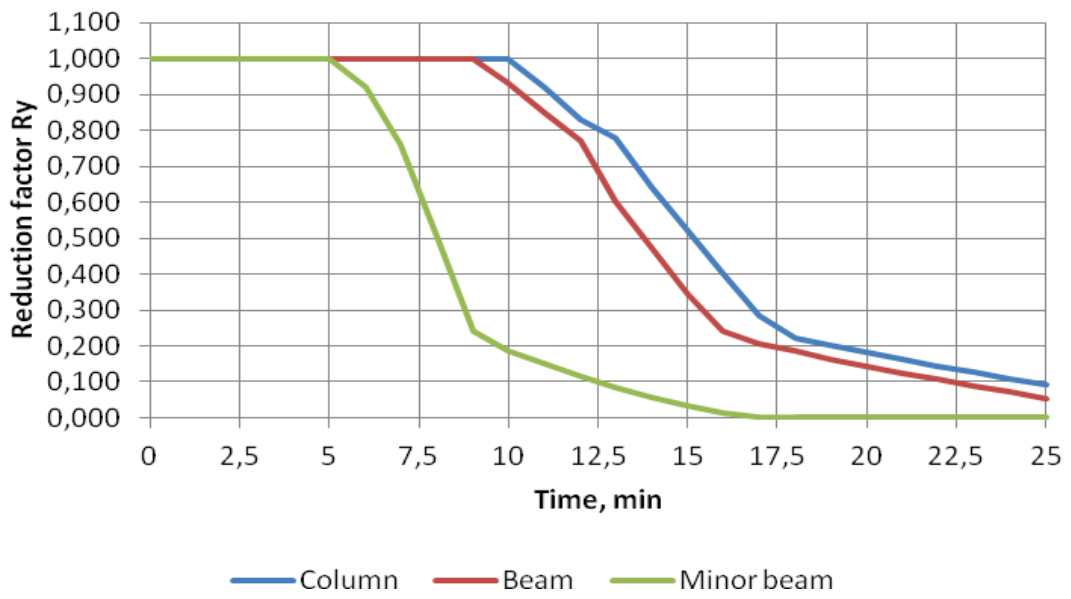




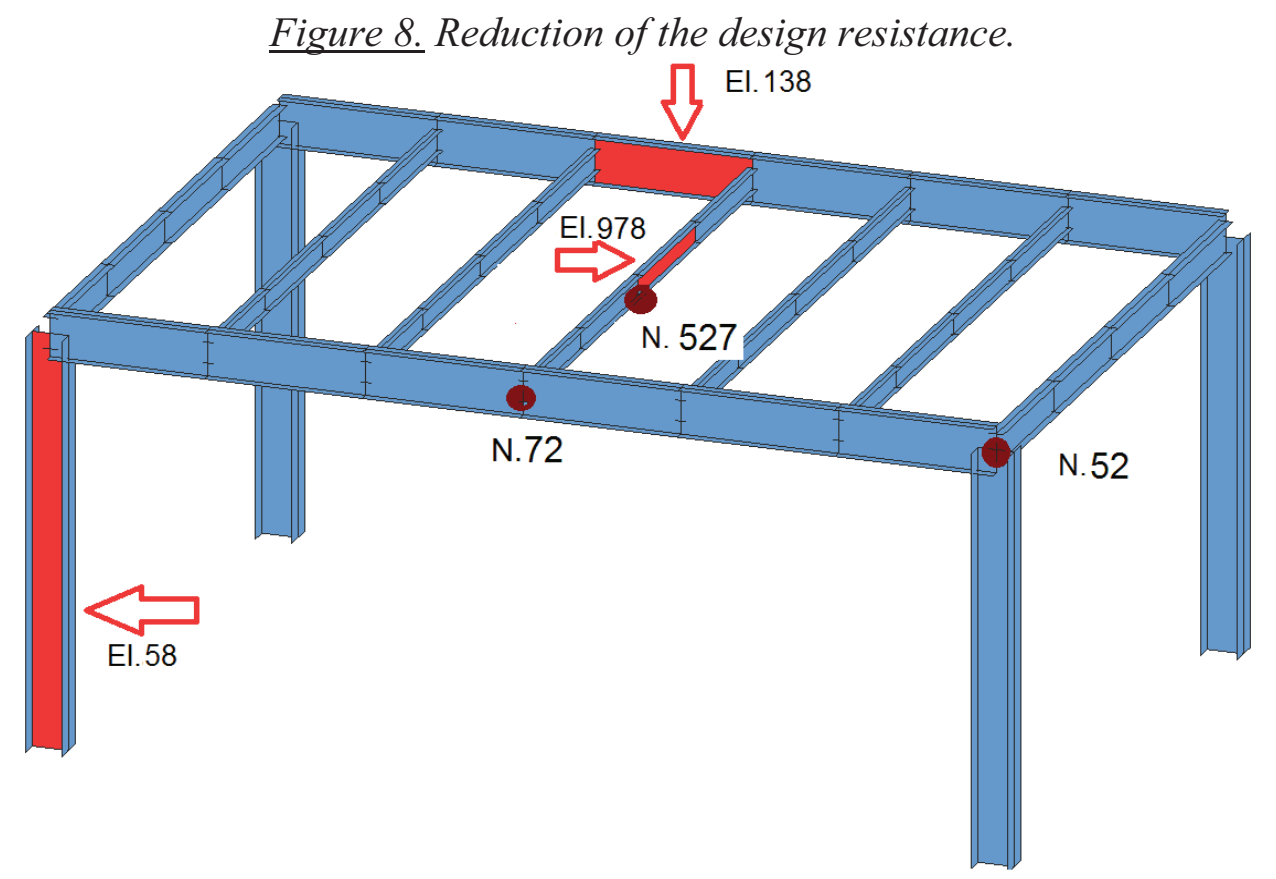

Figure 9. Controlled elements.

Table 2. The results of the calculation.

\begin{tabular}{|c|c|r|r|r|r|r|r|r|r|}
\hline \multirow{2}{*}{$\begin{array}{c}\text { Time, } \\
\text { min }\end{array}$} & \multicolumn{2}{|c|}{ Displacements, node 52 } & \multicolumn{4}{c|}{ Displacements, node 72 } & \multicolumn{3}{c|}{ Displacements, node 527 } \\
\cline { 2 - 10 } & $\mathrm{X}$ & $\mathrm{Y}$ & \multicolumn{1}{c|}{$\mathrm{Z}$} & $\mathrm{X}$ & $\mathrm{Y}$ & $\mathrm{Z}$ & \multicolumn{1}{c|}{$\mathrm{X}$} & $\mathrm{Y}$ & $\mathrm{Z}$ \\
\hline 0 & 0,18 & 0,01 & $-0,97$ & $-0,01$ & 0,01 & $-10,28$ & $-0,02$ & 0,00 & $-11,06$ \\
\hline 4 & 0,85 & $-2,09$ & 4,94 & $-0,39$ & $-1,52$ & $-13,74$ & $-0,21$ & $-0,41$ & $-23,39$ \\
\hline 8 & 1,14 & $-2,00$ & 11,11 & $-1,02$ & $-1,33$ & $-15,73$ & $-0,81$ & $-0,57$ & $-23,42$ \\
\hline 10 & 1,30 & $-2,25$ & 13,86 & $-1,20$ & $-1,50$ & $-20,42$ & $-0,95$ & $-0,67$ & $-29,14$ \\
\hline 12 & 1,34 & $-1,81$ & 16,52 & $-1,31$ & $-1,19$ & $-25,31$ & $-1,10$ & $-0,63$ & $-32,21$ \\
\hline 15 & 1,86 & $-0,53$ & 17,32 & $-0,42$ & $-0,42$ & $-38,06$ & $-0,34$ & $-0,24$ & $-42,18$ \\
\hline
\end{tabular}

The strength analysis was performed in SCAD (the Erection mode) for the state of the structure at the beginning of the fire and on the 4-th, 8-th, 10-th, 12-th and 15-th minute from the start of the fire. The results of the calculation are given below.

Internal forces are tracked in columns (finite element 58), the middle of the beam (finite element 138), and the middle of the minor beam (finite element 978). These elements are shown in Figure 9.

Control nodes 52, 72 and 527 are selected to track the displacements. They are shown in Figure 9 as well.

The results of the calculation are given in the Tables 2 and 3.
Beam strength failure occurs between 4-th and 8 -th minutes, minor beams fail on the 4-th minute, and columns fail between 8 -th and 10 -th minutes, although their temperature is far from the critical value (Fig. 10). The critical time is about 16 minutes for columns, 14 minutes for beams, and 11 minutes for minor beams.

The strong discrepancy is caused by a fundamental change in the type of the stress-strain state (drastic difference in eccentricities). In this example, the so-called secondary effects have created large longitudinal forces in the elements some of which were considered as only flexural. The fact that the fire area was a section of the floor turned out to be less favorable for the columns. If all columns on the floor were equally 
heated, the critical temperature estimate would be closer to the design behavior of the structure. Table 3. The results of the calculation.

\begin{tabular}{|c|c|c|c|c|c|c|c|c|c|}
\hline \multirow[b]{2}{*}{$\begin{array}{l}\text { Time, } \\
\min \end{array}$} & \multicolumn{3}{|c|}{ Forces in the element 58} & \multicolumn{3}{|c|}{$\begin{array}{c}\text { Forces in the element } \\
138\end{array}$} & \multicolumn{3}{|c|}{$\begin{array}{c}\text { Forces in the element } \\
978\end{array}$} \\
\hline & & & & & $\begin{array}{l}\mathrm{M}, \\
\mathrm{tm}\end{array}$ & $\mathrm{Q}$ & $\mathrm{N}$ & $\mathrm{M}, \mathrm{tm}$ & $\mathrm{Q}, \mathrm{t}$ \\
\hline 0 & -72 & & & -72 & 0.00 & 0 & 8. & 2.34 & .25 \\
\hline 4 & & & & -25 & 2.15 & 50 & -27 & 10.58 & 83 \\
\hline 8 & & & & -33 & 2.87 & 6.66 & -48 & 12.52 & 5.62 \\
\hline 10 & & & & -654 & 5.02 & 11.16 & -75 & 25.44 & 11.70 \\
\hline 1 & -48 & & & -480 & 2.03 & 5.07 & -512 & 13.64 & 6.15 \\
\hline 15 & -541.81 & -1.58 & 0.97 & -540.41 & 0.34 & 0.97 & -327.65 & 9.89 & 4.22 \\
\hline
\end{tabular}

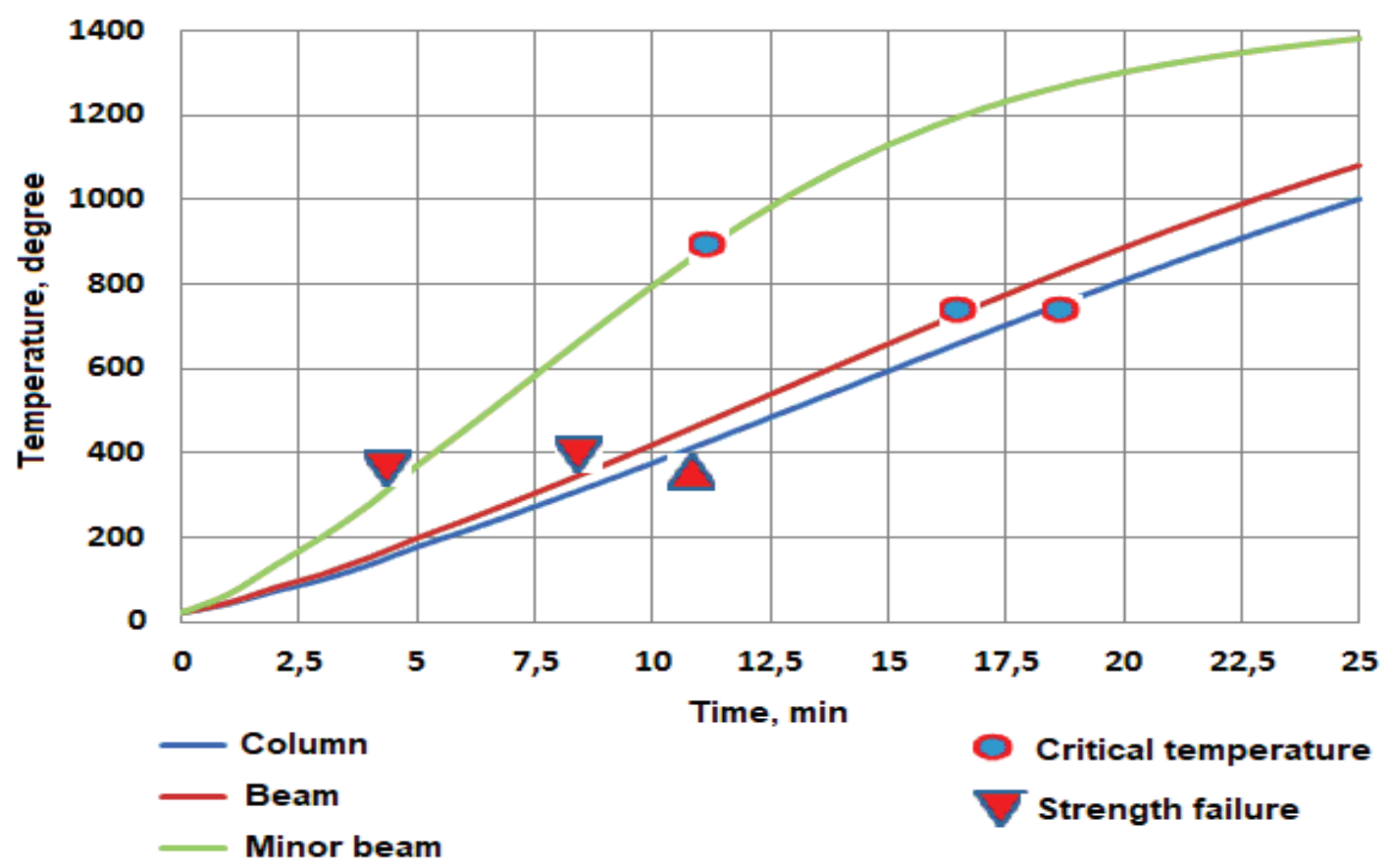

Figure 10. Comparison of results.

\section{CHALLENGING ISSUES}

All the above calculations are based on the strength check performed according to the codes (but taking into account changes in the yield strength and elastic modulus of steel). In other words, plasticity has been practically ignored.

If we assume deep plastic deformation, then additional forces from thermal heating can drop rapidly. This is evidenced by experiments carried out at the University of Sheffield (UK) by Allam A.V., Burgess I.W., Plank R.J. (Figures 11 and 12).
Moreover, it is necessary to answer the following important questions:

1. A building has different structural components with various fire resistance limits. The following question arises: should the calculation of the entire structure be performed to the minimum or to the maximum limit? This problem is not considered in European fire regulations, where fire resistance requirements are set not for individual components, but for the whole structure. 
2. It is not clear how to simulate a fire - which fire area should be considered when a structure is not divided into fire compartments.
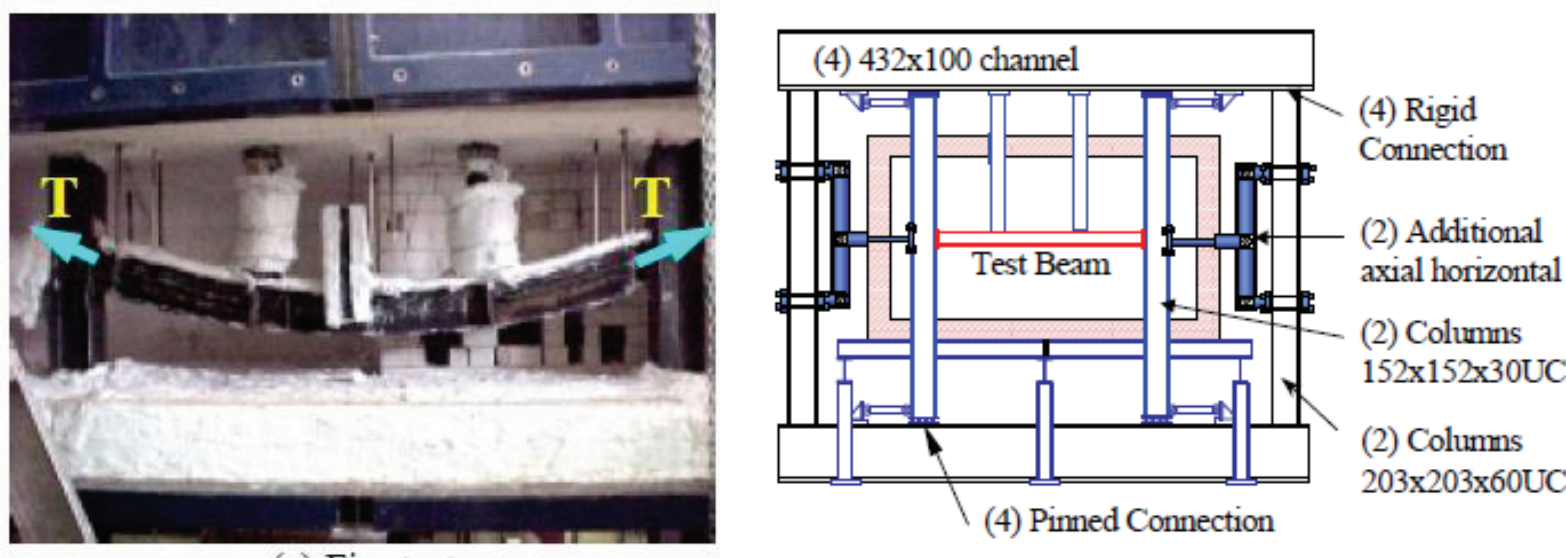

(4) Pinned Connection

Figure 11. Experimental setup.

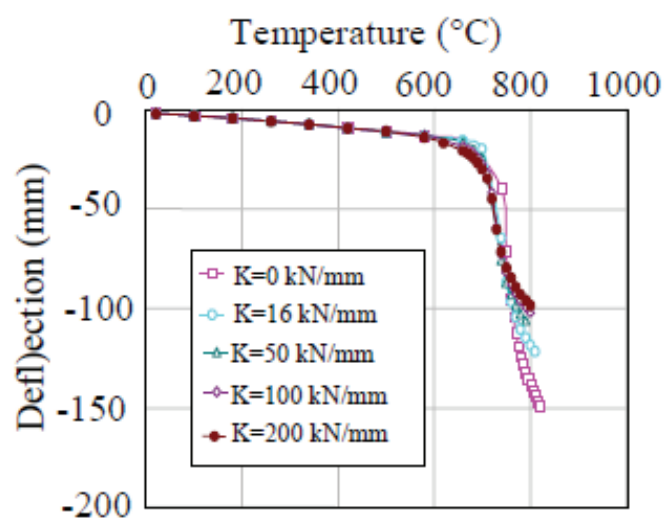

(a) Central deflection

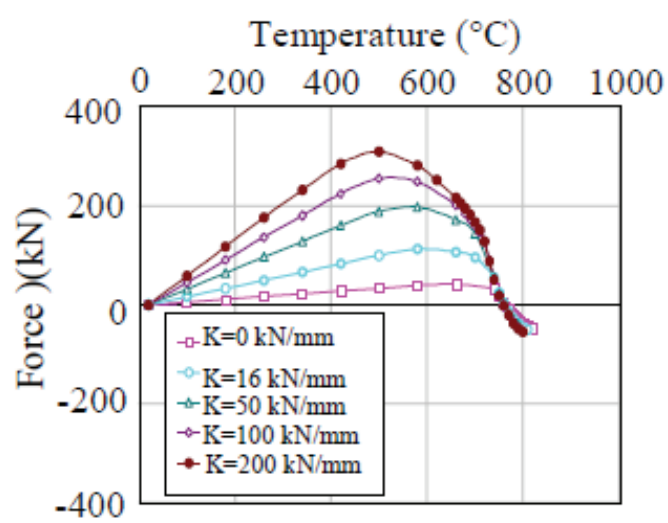

(b) Axial force in the tested beam

Figure 12. Fire test results.

\section{REFERENCES}

1. Allam A.M., Burgess I.W. and Plank R.J. Performance-Based Simplified Model for a Steel Beam at Large Deflection in Fire. // Proc. 4th International Conference on Performance-Based Codes and Fire Safety Design Methods, Melbourne, Australia, 2002.

2. Bailey C.G., Burgess I.W. and Plank R.J. Computer Simulation of a Full-Scale Structural Fire Test. // The Structural Engineer, 1996, Vol. 74, No. 6, pp. 93100.

3. EN 1993-1-2. Eurocode 3: Design of steel structures. General rules - Structural fire design. Brussels, CEN, 2010.
4. Poklonsky V.G., Fesenko O.A, Tarasyuk V.G. et al. Fire Design of Reinforced Concrete Structures According to Eurocode 2. Kiev, Intertekhnologiya, 2016, 83 pages.

5. Fedorov V.S., Levitsky V.E., Molchadsky I.S., Aleksandrov A.V. Ognestojkost' i Pozharnaja Opasnost' Stroitel'nyh Konstrukcij [Fire Resistance and Fire Hazard of Building Structures]. Moscow, ASV, 2009 (in Russian).

\section{СПИСОК ЛИТЕРАТУРЫ}

1. Allam A.M., Burgess I.W. and Plank R.J. Performance-Based Simplified Model for a Steel Beam at Large Deflection in Fire. // 
Proc. 4th International Conference on Performance-Based Codes and Fire Safety Design Methods, Melbourne, Australia, 2002.

2. Bailey C.G., Burgess I.W. and Plank R.J. Computer Simulation of a Full-Scale Structural Fire Test. // The Structural Engineer, 1996, Vol. 74, No. 6, pp. 93-100.

3. EN 1993-1-2. Eurocode 3: Design of steel structures. General rules - Structural fire design. Brussels, CEN, 2010.

4. Poklonsky V.G., Fesenko O.A, Tarasyuk V.G. et al. Fire Design of Reinforced Concrete Structures According to Eurocode 2. Kiev, Intertekhnologiya, 2016, 83 pages.

\section{5. Федоров В.С., Левитский В.E.,} Молчардский И.С., Александров А.В. Огнестойкость и пожарная опасность строительных конструкций. - М.: АСВ, 2009. -408 c.

Anatolii V. Perelmuter, Foreign member of Russian Academy of Architecture and Construction Sciences, Doctor of Science, Professor; SCAD Soft, Ltd; Kiev 03037, Ukraine, 3a Osvity street, office. 1,2; phones: +380442497193 (91), +380442487100, +38044 24880 60; e-mail: avp@scadsoft.com.

Перельмутер Анатолий Викторович, иностранный член РААСН, доктор технических наук, профессор; НПО СКАД Софт, 03037, Украина, г. Киев, ул. Просвящения, 3а, Офис 2; тел. +38 0442497193 (91), +3804424871 00, +3804424880 60;

E-mail:avp@scadsoft.com. 